\title{
Journal of Earth and Environmental Sciences Research
}

First Record and Massive Spread of Tropical Long-Spined Sea Urchin Diadema antillarum in the Mediterranean Sea (Syrian Coast)

\author{
Izdihar Ali Ammar \\ Professor, Marine Biology Department, High Institute of Marine Research, Tishreen University, Lattakia, Syria
}

\begin{abstract}
The biological structure of the Syrian marine environment still shows a rapid and steady increase in the number of warm water species, many of which have become dominant and invasive.

In the latest field data during 2020-2021, the presence of the black sea urchin Diadema antillarum (Philippi, 1845) was recorded for the first time in several locations in Latakia and Ras al-Bassit coast, and its massive spread at depths of 5-8 m, accompanied by invasive species of macroalgae, sponges, crustaceans and mollusks.. It is noteworthy that this species is one of the most widespread and important species of sea urchins in some tropical areas, and this is the first record in the Mediterranean Sea and the Syrian coast It is important as it prey on macroalgae and has an effective role in the health of some of the most important areas of biodiversity in the world.
\end{abstract}

\section{${ }^{*}$ Corresponding author}

Izdihar Ali Ammar, Professor, Marine Biology Department, High Institute of Marine Research, Tishreen University, Lattakia, Syria. Email: izdiammar@gmail.com

Received: October 16, 2021; Accepted: October 21, 2021; Published: October 29, 2021

Keywords: Black sea urchin, Long-spined sea urchin, Diadematidae, Coralligenous structure, Syrian shore, Invasive alien species

\section{Introduction}

Day by day, the presence of more invasive alien species continues to be recorded in the Syrian marine waters. The geographical site of the Syrian coast with its concentration in the eastern basin of the Mediterranean and its proximity to the Suez Canal have helped in the success of more invasive species of Indo-Pacific origin and those belonging to Fauna. of Red Sea "Lessepsian migrants" in colonize this area, in addition to the active movement of ships and maritime transport in the Mediterranean, which contributed greatly to the emergence of new alien species, most of these species have been documented through many published articles, an updated list of these species has also been developed, all of these results came within the framework of implementing many projects and researches related to marine biodiversity, the most recent of these research is a project supported by the Higher Commission for Scientific Research in Syria, which is concerned with assessment of the status of alien and invasive benthic species in the Syrian marine environment [1-6]. Many of the alien species that were first recorded in the Mediterranean and Syria during the past few years belong to the Cephalopods and Sponges, and species of Red and Brown algae, in 2019 the presence of the first marine crabs of Atlantic origin was documented in the Syrian coast and the eastern Mediterranean [7-10].
For alien Echinoderms, two species were recorded in Syria, the first of the serpent stars, Ophiactis macrolepidota was reported for the first time at a depth of 7-11 $\mathrm{m}$ in the rocky beach in Latakia and it was also found abundantly among sponges Ircinia spp [11]. In the Ras al-Bassit region (current study), Sea cucumber Synaptula reciprocans, of Holothuroidea, was found in al-Samra and Ibn Hani in 2003 in the Cymodocea nodosa meadows at depths of 12-32 m, currently, it is widespread in the port of Al-Bassit at a depth of $3 \mathrm{~m}$ [11]. As for sea urchins, many native species have continued to appear since the early nineties of the last century including: Paracentrotus lividus, Psammechinus miliars, Arbacia lixula, Cidaris cidaris, Centroctephanus longispinus [12,13].

The presence of these species has declined in the Syrian shores for several years and has reappeared again. The current study documents the presence of Diadema antillarum (Philippi, 1845) of the Diadematidae family for the first time in the Mediterranean and Syria.

\section{Materials and Methods}

Many Individuals of Diadema antillarum were collected for the first time from the shallow water by free diving at depths 5-8 from Fanar Ibn Hani marine protected area at the north of Latakia. Figure (1), during October 2020, more individuals were collecting during January 2021, the presence of the species was documented by underwater camera. 


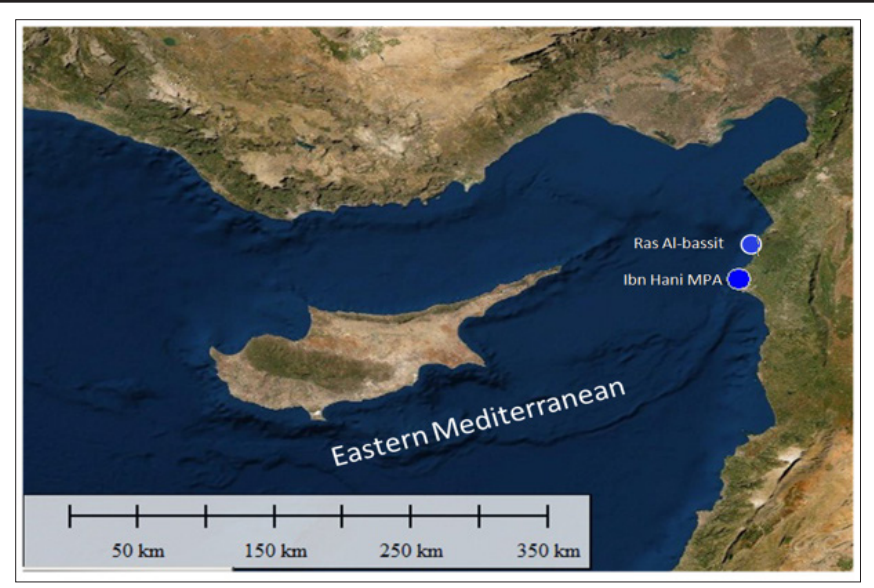

Figure 1: Map showing the study area of the Syrian coast (Eastern Mediterranean)

\section{Results and Discussion}

Field work and information available by fishermen indicate the dominance of Diadema antillarum in rocky substrates at depths of 5-8 m. along the coast of the Fanar Ibn Hani Marine protect area, and for several hundred meters in the south and north. The presence of large numbers of it was also monitored in Ras alBassit, specifically within the marina, at depths of $3 \mathrm{~m}$, about 40 $\mathrm{km}$ from the Fanar Ibn Hani MPA.

Diadema antillarum belongs to the family Diadematidae of the phylum Echinodermata, class Echinoidea, and the order Diadematoida [14].

$\begin{array}{ll}\text { Kingdom } & \text { : Animalia } \\ \text { Phylum } & \text { : Echinodermata } \\ \text { Class } & \text { : Echinoidea } \\ \text { Order } & \text { : Diadematoida } \\ \text { Family } & \text { : Diadematidae } \\ \text { Genus } & \text { : Diadema } \\ \text { Species } & \text { : D. antillarum }\end{array}$

This species is known as the black sea urchin or the long-spined sea urchin and is one of the most widespread and important species of sea urchins in some tropical regions, abundant in the shallow waters of the Gulf of Mexico and the Caribbean Sea, the western Atlantic and the northeastern shores for south American countries such as Colombia, Venezuela, Brazil, the Canary Islands, the eastern Atlantic and some areas of the Indian Ocean [15].

This species usually lives on hard and soft surfaces in shallow waters and its spread extends to a depth of hundreds of meters [16]. They often live in coral reefs at depths of 1-10 m. On the Syrian coast, it was observed in rocky crevices and exposed substrates at depths of 3-8 m (Figure 2a). This species is is the most important and abundant herbivorous species in coral reef areas. It devours macroalgae of various groups which can overgrow in reef areas to the point that they can suffocate the reef. It also feeds on detritus and sediment and becomes carnivorous when hungry.

The activity of this species is nocturnal, roving within one meter of its dwelling to get its food, and it is very sensitive to light. It is a prey for other invasive fish species, such as surgeonfish, porcupine fish, and species of gastropods.

Diadema antillarum is characterized by a regular spherical body and radially symmetrical, with long black spines, which range between $10-12 \mathrm{~cm}$ and may reach up to $30 \mathrm{~cm}$ in very large individuals. The length of the spin in the largest individuals collected from Al-Bassit marina ranged between $29-30 \mathrm{~cm}$ (Figure $2 \mathrm{~b}$ ), a central mouth on the lower side (Figure 2c). The central anus is also located on the upper side (Fig. 2d). It is often black and sometimes white

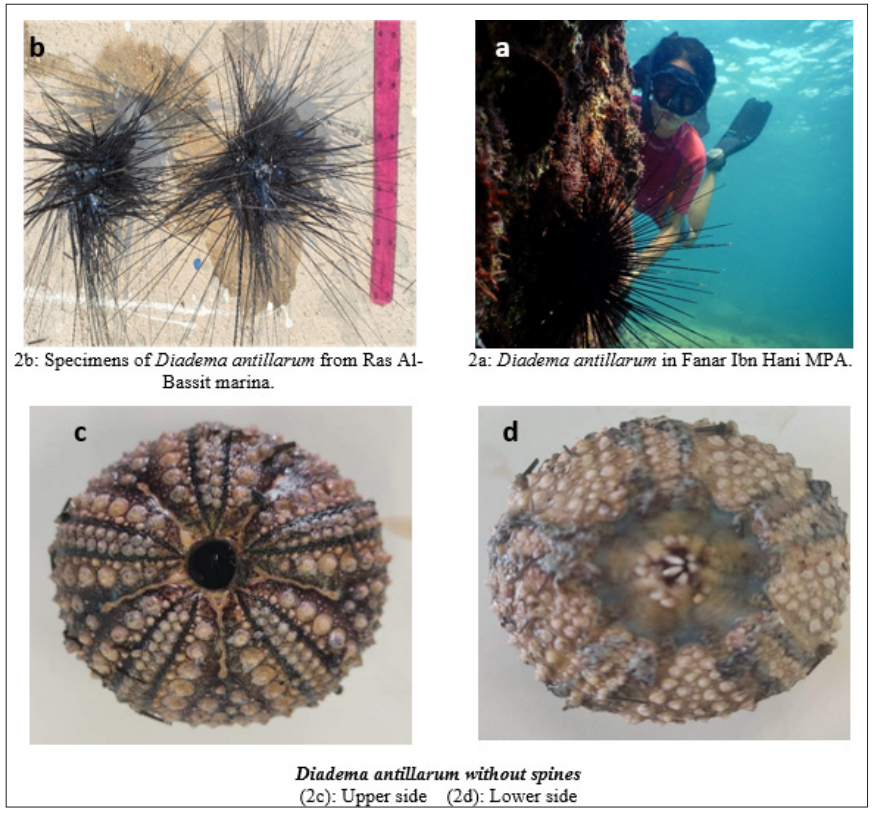

Figure 2: Diadema antillarum specimens from the Syrian coast

The environmental changes and the warming of the eastern Mediterranean basin may be the reason for the success of many benthic species in moving from the western and eastern Atlantic and reaching the eastern Mediterranean through the Strait of Gibraltar As well as the presence of coralligenous and calcareous bio-concretions environments and structures suitable for the settlement of these species along the Syrian coast [16-21].

Environmental status of Diadema antillarum in the Syrian coast This species has appeared in the Syrian marine environment since October of 2020, in the shallow coastal area within Fanar Ibn Hani MPA., at depths ranging between 5-8 m. Subsequent field data indicate the expansion of its spreading to reach Ras al-Bassit in the north, with large numbers and large sizes as well.

Some individuals were collected at the beginning of the year 2021 at a depth of $6 \mathrm{~m}$ by free-diving, where several species of sessile animals such as sponges, ascidians and mollusks appeared in the sea urchin grazing areas on the coraligenous reefs in the MPA. the Mediterranean urchin Psammechinus microyuberculatus and three species of sponges Hippospongia communis, Ircinia sp. Chondrosia reniformis been found, in addition to some individuals of hairy crab Eriphia verrucosa and three species of alien invasive bivalves are: Pinctada radiata, Chama pacifica, Spondylus spinosus plus Phallosia nigra of the invasive Ascidians (Figure 3a).

The spread of this invasive urchin in the MPA. was also accompanied by a massive spread and emergence of the invasive red algae Asparagopsia taxiformes Montagne (Rhodophyta, Bonnemaisoniales) (Figure 3b) [22,23]. In addition to two species of green algae, Cystoseira and Ulva fasciatac, the most common algae in the rocky reef were the following crustose and coralline algae:

Lithophyllum incrustans, Jania rubens, Galaxaura rogusa, Codium arabicum, C. taylorii, C. parvulum, Polysiphonia ferulacea 


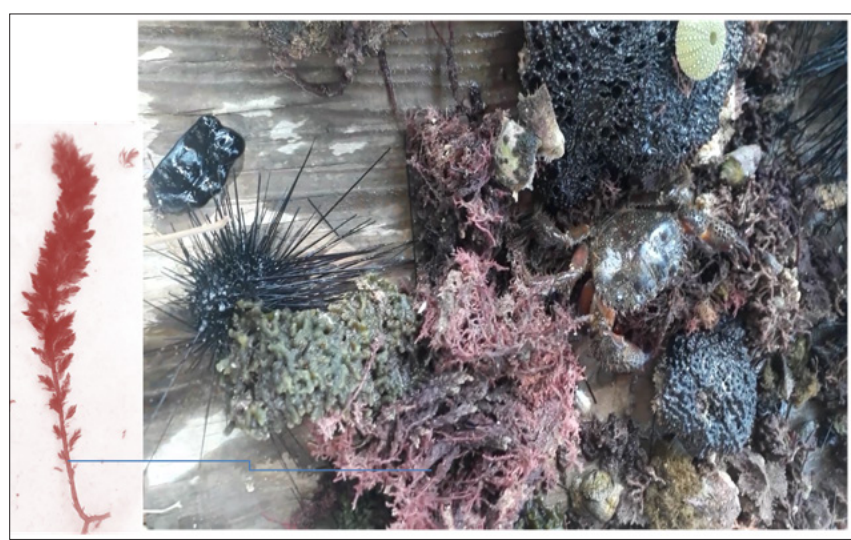

Figure 3a: Sea urchin and its associated benthic species in Fanar Ibn Hani MPA.

Figure 3b: Invasive red alga Asparagopsia taxiformes associated the sea urchin.

The nutritional and medical importance of this species is unknown yet, but its ecological importance and its impact on sea food chains and marine biodiversity is great. It is clear that the two species Padina and Dictyota spp of brown macroalgae is absent from the MPA., and this is explained by the fact that Diadema antillarum devoured them and slowed their growth, which allowed an increase in the number of the rest of smaller algae. In Ras Al-bassit marina, the algae is completely absent, it seems that the Diadema antillarum has adapted to the absence of algae and shifted to feed on detritus, while the absence of predator fish for this urchin due to overfishing is the main reason for increasing its numbers in the Syrian coast

\section{Conclusion}

Finally, the settlement of this alien species in the Syrian marine waters and the speed of its reproduction, spread and dominance in the new environment without direct human intervention makes it an invasive species. The rapid globalization and trends of trade and maritime transport may play a role in the introducing of black urchin and accelerating their invasion by transferring them outside its current range. It will therefore be necessary to assess the existence of this species, the reason for its introduction, its expansion, and its potential impacts on fisheries.

\section{References}

1. Kucheruk NOV, Kuznetsov AP, Rybmikov AV, Saker F (1998) Composition of bottom and quantitave distribution of macrozoobenthos in Syrian coastal water. Chapter: The Eastern Mediterranean as a Laboratory Basin for the Assessment of Contrasting Ecosystems NATO Science Series 51: 159-168.

2. Ammar I (2004) Benthic fauna of the Syrian coast/ assessment of the state of migrant and invader species. 37th CIESM Congress, Barcelona, Conference abstracts 473p.

3. Zenetos A, Gofas S, Morri A, Rosso A (2012) Alien species in the Mediterranean Sea by 2012. A contribution to the application of European Union's Marine Strategy Framework Directive (MSFD). Part 2. Introduction trends and pathways. Mediterranean Marine Science, 13: 328-352.

4. Katsanevakis S, Acar Ü, Ammar I, Balci B., Bekas P (2014) New Mediterranean Biodiversity Records (October, 2014) Mediterranean Marine Science 15: 667-687.

5. Ammar I (2019) Updated list of alien macrozoobenthic species along the Syrian coast. International Journal of
Aquatic Biology 7: 180-194.

6. Ammar I A, Arraj H, Alshawy F, Wong L J, Pagad S (2020) Global Register of Introduced and Invasive SpeciesSyrian Arab Republic Invasive Species Specialist Group ISSG. Dataset/Checklist. https://cloud.gbif.org/griis/ resource? $\mathrm{r}=$ griis-syria\& $\mathrm{v}=1.4$.

7. Ammar I, Maaroof M (2019) First Record of the Squid Sepioteuthis Lessoniana Férussac, 1831 in the Syrian Coastal Water International Journal of Agriculture \& Environmental Science 6: 52-55.

8. Ammar I, Fadel S (2017) Update list of sponges of Lattakia (Syria)-New Record exotic species. Journal of Entomology and Zoology Studies 5: 1041-1047.

9. Arraj H, Mayhoob H, Abbas A (2016) First records of two Padina species (Dictyotales, Phaeophyceae) from the Syrian coast (eastern Mediterranean) Marine Biodiversity Records 9: 93.

10. Ammar I, Khalifa F (2019) First record of Brachynotus atlanticus Forest, 1957 (Decapoda, Varunidae) from Syrian coast Species. Report 20:151-153.

11. Bitar G, Dupuy de la Grandrive R, Foulquié M (2003) Second mission relating to the development of marineprotected areas in Syrian coasts 1-18. Available at: http://medmpa. rac-spa. org/pdf/Rapports

12. Ammar I (1995) A qualitative and quantitative study of zoobenethos in Latakia coast. Master's thesis in aquatic environment, Faculty of Science, Tishreen University 171.

13. Ammar I (2002) Study of zoobenethos in Banias coast and the effect of petroleum hydrocarbons on them, $\mathrm{PhD}$ thesis in the aquatic environment, Faculty of Science, Tishreen University 336pp.

14. Kroh A, Mooi R (2021) World Echinoidea Database. Diadema antillarum (Philippi, 1845). Accessed through: World Register of Marine Species at: http://www.marinespecies.org/aphia. php? $\mathrm{p}=$ taxdetails\&id $=124332$ on 2021-10-09.

15. WoRMS Editorial Board (2021) World Register of Marine Species. Available from http://www.marinespecies.org at VLIZ. Accessed 2021-10-07. doi:10.14284/170.

16. Sterrer CS (1986) Marine Fauna and Flora of Bermuda: A Systematic Guide to the Identification of Marine Organisms. New York: John Wiley and Sons. 742pp.

17. Lenda M, Skórka P, Knops JM (2014) Effect of the internet commerce on dispersal modes of invasive alien species. PLoS One 9 : e99786.

18. van Kleunen M, Dawson W, Essl F (2015) Global exchange and accumulation of non-native plants. Nature 525:100-103

19. Canning-Clode J (2016) Biological Invasions in ChangingEcosystems: Vectors, Ecological Impacts, Management and Predictions. De Gruyter Open 474p.

20. Frances E L, Roy H, Simpson A, James TC, Hanson JM, et al. (2016) INVASIVESNET towards an International Association for Open Knowledge. on Invasive Alien Species Management of Biological Invasions. 7: 131-139.

21. Ingrosso $\mathrm{G}$, Abbiati $\mathrm{M}$, Badalamenti $\mathrm{F}$, Bavestrello $\mathrm{G}$, Belmonte G, et al. (2018) Mediterranean Bioconstructions Along the Italian Coast. Advances in marine biology 79: 61-136.

22. Torchia G, Badalamenti F, Ammar I (2004) First data on the biocœnotic characteristics of a marine protected area along the Syrian coast. $35^{\circ}$ Congress odella Società Italiana di Biologia Marina onlusGenova 19-20.

23. Otero M, Cebrian E, Francour P, Galil B, Savini D (2013) Monitoring Marine Invasive Species in Mediterranean Marine Protected Areas (MPAs): A Strategy and Practical Guide for 
Managers; IUCN: Malaga, Spain 136p.

24. Silva CO, Novais SC, Soares AMVM, Barata C, Lemos MFL (2021) Impacts of the Invasive Seaweed Asparagopsis armata Exudate on Energetic Metabolism of Rock Pool Invertebrates. Toxins 202:1 13-15. https://dx.doi.org/10.3390/ toxins 13010015 . 